\title{
The BA-BCS 2021: An Initial “Trial” for Integrating Basic Science and Medical Progress on Breast Cancer in a Latin-American Country
}

\author{
Edith Kordon ${ }^{1} \cdot$ Claudia Lanari $^{2} \cdot$ Pablo Mando $^{3} \cdot$ Virginia Novaro $^{2} \cdot$ Mario Rossi $^{4} \cdot$ Marina Simian $^{5}$
}

Received: 1 September 2021 / Accepted: 1 October 2021 / Published online: 12 October 2021

(c) The Author(s), under exclusive licence to Springer Science+Business Media, LLC, part of Springer Nature 2021

\begin{abstract}
The first Buenos Aires Breast Cancer Symposium (BA-BCS) was held in a virtual format, between the $17^{\text {th }}$ and the $21^{\text {st }}$ of May 2021. The main goal of the meeting was to facilitate the interaction among physicians and basic researchers from South America and with peers from the rest of the world. To embrace their different interests and concerns, the congress included not only talks on basic, translational and clinical research, but also round tables to discuss diagnostic methods, research financing and biobank management, as well as virtual poster sessions in which the youngest fellows presented their recent findings. This report provides a brief overview of the talks delivered during the meeting, which addressed a wide variety of vital issues for breast cancer research mostly focused on the accurate diagnosis, prevention and treatment of this illness. The presentations included a wide spectrum of themes including hormone receptors and the relevance of their mutations, immunotherapy, cancer stem cells, mouse models, environmental hazards, genetics and epigenetics, local and systemic therapies, liquid biopsies, the metastatic cascade, therapy resistance and dormancy, among others.
\end{abstract}

Keywords Breast cancer $\cdot$ Clinical trials $\cdot$ Experimental models $\cdot$ Advances in diagnosis and treatments

$\begin{array}{ll}\text { Abbreviations } \\ \text { BCSC } & \text { Breast cancer stem cell } \\ \text { ER } & \text { Estrogen receptor } \\ \text { MIND } & \text { Mammary intraductal model } \\ \text { PDX } & \text { Patient-derived xenograft } \\ \text { PR } & \text { Progesterone receptor } \\ \text { SERM } & \text { Selective ER modulator } \\ \text { TNBC } & \text { Triple-negative breast cancer }\end{array}$

Edith Kordon

ekordon@qb.fcen.uba.ar

1 Instituto de Fisiología, Biología Molecular Y Neurociencias (IFIBYNE-UBA-CONICET)), Facultad de Ciencias Exactas y Naturales, Departamento de Química Biológica, Universidad de Buenos Aires, 1428 Ciudad Autónoma de Buenos Aires (CABA), Argentina

2 Instituto de Biología Y Medicina Experimental (IBYME-CONICET), CABA, Argentina

3 CEMIC, CABA, Argentina

4 Instituto de Investigaciones en Medicina Traslacional (IIMT), Universidad Austral-CONICET, Provincia de Buenos Aires, Pilar, Argentina

5 Instituto de Nanosistemas, Universidad Nacional de San Martín, Provincia de Buenos Aires, San Martín, Argentina
The first Buenos Aires Breast Cancer Symposium was planned to be held on May 2020 at the Usina de Arte, a beautiful, huge historical building in the traditional La Boca district in Buenos Aires, capital city of Argentina. The main goal of the meeting was to expose young Latin American oncologists and investigators to the state of the art in breast cancer research and treatment. In the last years, the possibility of travelling abroad to participate in meetings has been almost prohibitive for local scientists and fellows, even before the pandemic. So we thought, if our scientists cannot travel abroad, we have to take the international research community to Argentina, and that was the leitmotif of our project. But, between February and March 2020 the COVID19 pandemic spread around the world. In April we were optimistic enough to postpone our meeting to October. Almost all speakers agreed on the new date, but of course we had to cancel once again. By November, we decided that we had to move to a virtual format. Once more, we wrote to all our original speakers and most of them accepted this new format.

During the virtual meeting we enjoyed 2 lectures, 27 talks from invited speakers in 13 thematic mini-symposia, 3 round tables and 81 posters, from which 11, all unpublished when submitted, were selected by the Scientific Committee integrated by Omar Coso and Albana Gattelli from 
IFIBYNE-UBA-CONICET, Buenos Aires, Argentina; Maria Roque (IHEM-CONICET, University of Cuyo, Mendoza, Argentina), Gaston Soria (CIBICI-CONICET, UNC, Córdoba, Argentina), Alfredo Molinolo and J. Silvio Gutkind (both from Moores Cancer Center, UCSD, San Diego, USA) to be discussed in the mini-symposia. The other accepted abstracts were presented in 4 sessions, each of which had between 85 to 110 attendees from different institutions from Argentina and other countries including Chile, Portugal, USA and UK. They were one of the meeting highlights, in which $\mathrm{PhD}$ students and postdoctoral fellows presented their unpublished results to the general audience in 4 min talks, with the possibility to continue the discussions with smaller groups in "private" google-meet "rooms" assigned to each poster.

In the opening conference, "Advances in Estrogen Receptor (ER) Targeted Approaches to Breast Cancer", Dr. Geoffrey Greene (University of Chicago, Chicago, USA) took us on a journey of his pioneering discoveries, starting with the purification of the ER protein, the development of the first antibodies against ER $\alpha$ [1], the cloning of the ER gene [2], and the use of $x$-ray crystallography to understand how agonists and antagonists work [3]. He then moved on to his recent and novel discoveries of ESR1 mutations in metastatic breast cancers [4] and the use of new selective estrogen receptor modulators (SERMs) to target them. He also showed data from the mammary intraductal model (MIND), a variant of the patient-derived xenograft (PDX) animal model that has led to new clinical trials of lasofoxifene [5]. In addition, he is currently studying the potential protective benefit of a recently approved hormone replacement therapy that combines an estrogen with a SERM. In summary, Dr. Greene showed not only that he has played a fundamental role in pivotal discoveries, but that he is still carrying out cutting edge research in the field.

The first minisymposium was focused on tumor heterogeneity and breast cancer therapy. Our invited speakers were Dr. Mohamed Bentites-Alj (University of Basel, Basel, Switzerland), Dr. Jorge Reis Filho (Memorial Sloan Kettering Cancer Center, New York City, USA) and Dr. Catalina Lodillinsky, a young scientist working at Ángel H. Roffo Institute, Buenos Aires, Argentina, whose abstract was selected by the scientific committee. Dr. Bentires-Alj gave a very interesting presentation showing the effect of the oxidoreductase ERO1A, which enhances HIF1 $\alpha$-VEGFA-mediated angiogenesis and metastatic colonization [6]. He also showed that the increase in stress hormones during breast cancer progression resulted in the activation of the glucocorticoid receptor, increased lung metastases and reduced overall survival in preclinical models [7]. Next, Dr. Reis Filho clearly showed how triple negative breast cancer (TNBC) is actually a diverse group of diseases. He emphasized that a subset of rare low-grade TNBCs, such as secretory carcinomas, adenoid cystic carcinomas or adenomyoepitheliomas, harbor recurrent genetic alterations and lack TP53 mutations. The correlations between histological features in this subset of tumors, and their genomic alterations, open the door to tailor the treatment decisions for patients with TNBC according to the histological type $[8,9]$. Finally, Dr. Lodillinsky referred to the kinase NME1 as a potent inhibitor of breast cancer progression and her research on the molecular mechanisms involved in its activity [10].

In the second session, Dr. Carol Lange, from University of Minnesota, Minneapolis, USA, highlighted the importance of progesterone receptor (PR) and glucocorticoid receptor phosphorylation in ligand-independent transcriptional regulation of target genes required for breast cancer stem cell expansion, which may open the way to new treatments [11, 12]. The next three presentations addressed the impact of modulating the tumor microenvironment in breast cancer progression. Dr. Jennifer Richer from University of Colorado, Aurora, USA, showed that targeting enzymes involved in tryptophan catabolism may reduce tumor progression by enhancing the anti-tumor immune response. She also emphasized the similarities between the mechanisms of immune suppression during pregnancy that ensure fetal tolerance and the immune suppressive mechanisms utilized by breast cancer. The hope is that further understanding of the hormonal regulation and reversible nature of the former can lead to ways to control the process during cancer [13]. Dr. Mariana Salatino (IBYME-CONICET, Buenos Aires, Argentina) focused on a new role for the antiprogestin mifepristone that reduced tumor growth and induced immunogenic cell death in a luminal mouse breast cancer model showing higher levels of isoform A than isoform B of PR [14]. Finally, the post-doctoral fellow Dr. Andrés Marcos Castellaro, from Dr. Germán Gil's lab at National University of Córdoba, Córdoba, Argentina, provided further evidence, based on their previous studies [15], on how conditioned macrophages may induce tumor growth and endocrine resistance through ER hyperphosphorylation and activation of the NF- $\kappa B$ pathway.

Breast Cancer Stem Cells (BCSC) and the de-differentiated phenotype were the topics of the following session, which included 3 speakers from European laboratories plus a short talk by a local PhD student. First, Dr. Jochen Maurer from University Hospital RWTH, Aachen, Germany, described his method to isolate, characterize, and propagate BCSC from triple-negative tumors after chemotherapy, and how it can be used as a tool to screen and test novel therapeutic agents [16]. Then Dr. Paolo Ceppi (University of Southern Denmark, Odense, Denmark) explained the relevance of metabolic pathways associated to the epithelial-to-mesenchymal transition and the stem cell-like phenotype [17]. Dr. Robert Clarke, from University of Manchester, UK, referred to the crucial role of bone marrow-derived cytokines for stimulating breast 
cancer cell colonization in the bone. The data obtained by his group revealed that IL1 $\beta$ induces intracellular NFKB and CREB signaling in breast cancer cells, which lead to Wnt ligand secretion, autocrine Wnt signaling activation and CSC colony formation. Therefore, inhibiting this pathway could be an important strategy to prevent bone metastasis formation [18]. Finally, Martín García Solá from Dr. Kordon’s Laboratory (IFIBYNE-UBA-CONICET, Buenos Aires, Argentina) showed that bio-informatic integration of multiple scRNA-seq data-sets provides new insights into mammary gland development [19].

The contribution of mouse models to new breakthrough discoveries for breast cancer prevention and treatment was the theme of Session 4. The first talk by Dr. Joseph Jerry from University of Massachusetts, Amherst, USA, was focused on the identification of mechanisms by which exposure to endogenous hormones and environmental chemicals may impact on inherited breast cancer risk. To this end, Dr. Jerry mapped a locus in mouse chromosome 7 that includes a genetic modifier, which may regulate repair of estrogeninduced DNA damage and would be responsible for the variable mammary tumor risk in different mouse strains [20]. Next, Dr. Fariba Behbod (University of Kansas, Kansas City, USA) focused her talk on the MIND model that allows the in vivo analysis of ductal carcinoma in situ (DCIS) progression. She showed the relevance of the BCL9-STAT3 pathway to DCIS invasive progression [21] and discussed efforts to "humanize" the MIND model to include the study of the immune system during DCIS evolution. Dr. William Muller, from Rosalind and Morris Goodman Cancer Center, Montreal, Canada, showed that upon ablation of the canonical mTORC1 activator (Rhebl) in multiple transgenic mouse models, mammary tumors display mTOR gene mutations that allow constitutive activation of the kinase, indicating that mTORC1 activation is required for mammary tumor initiation [22]. Finally, Dr. Diego Grinman, a postdoctoral fellow at Dr. Wysolmerski's laboratory (Yale School of Medicine, New Haven, USA) showed his recent results indicating that mammary tumor expression of parathyroid hormone-related protein (PTHrP) contributes to cancer progression and causes anorexia, possibly, through a calcium dependent mechanism.

The sixth session focused on the relevance of genetic and epigenetic alterations in breast cancer progression and their relationship with environmental hazards. Dr. Adrian Lee from University of Pittsburgh, USA, described the state-ofthe-art techniques for functional genomics characterization of breast cancer disease, highlighting the heterogeneity and diversity between primary breast carcinomas, local recurrent tumors, and the metastatic ones at genomics and transcriptomics levels. Evolution of changes in progression to metastasis is now well described and highlights not only mechanisms of drug resistance but also new therapeutic targets [23-25]. Next talk, by Dr. Sophie Lelièvre (Institut de Cancérologie de l'Ouest, Pays de la Loire, France) was centered on environmental challenges and cancer risk build-up. She presented an interesting risk-on-chip model to analyze the additive effects of microenvironmental stressors, such as increased reactive oxygen species and matrix stiffness, on the epigenome of the breast epithelium. Her collaborative results showed how pathways linked to oxidative stress synergize with the pesticide Glyphosate that influences the activity of TET demethylating enzymes to trigger tumor onset. She insisted on the importance of combining cell culture-based risk models and clinical data to help identify epigenetically controlled noncoding RNAs that may serve the evaluation of breast cancer risk [26-28]. Dr. Guenter Vollmer, from Technische Universität Dresden, Germany, showed that natural botanical extracts obtained from hops or honeybush, for example, may represent promising tools for a preventive strategy for hormone-dependent breast cancer. This is due to the negative impact on the activity of ER $\alpha$ in the breast, following the parallel activation of ER $\beta$ [29] or the aryl hydrocarbon receptor pathways by these extracts $[30,31]$. Selected from poster abstracts, Santiago Madera's talk referred to the continuity of pioneering discoveries by Dr. P. V. Elizalde's group (IBYME-CONICET, Buenos Aires, Argentina) on the role of nuclear ErbB-2 in ErbB2-positive breast cancer [32-34]. Using transcriptomic and preclinical approaches he provided evidence indicating that nuclear ErbB-2 can be considered a therapeutic target in trastuzumab-resistant breast cancer.

The topics of mechano-signaling and the role of extracellular matrix stiffness by Dr. Valerie Weaver (University of California, San Francisco, USA.), the intricate functional mechanism acting at the tumor microenvironment of metastasis by Dr. John Condeelis (Albert Einstein Cancer Center, Bronx, USA) and the importance of disseminated cancer cell dormancy regulation by Dr. Julio Aguirre Ghiso (Icahn School of Medicine at Mount Sinai, New York City, USA) were addressed in Session 7. Throughout the presentations we learned about the key role that the interaction between BCSC and the microenvironment plays in the regulation of invasion and dormancy. Moreover, we saw how translational research approaches combining cutting edge technology, molecular biology and clinical research have allowed to move forward and advance to the point where several clinical trials are in progress, or about to start. This highlights the fact that, most likely, these lines of research might represent new points for therapeutic intervention to develop treatments for metastatic cancer in the near future [35-38]. In addition, we had two excellent talks also related to the metastatic process, selected from the posters, describing ongoing lines of research involving the use of the hemostatic compound desmopressin as a repurposed drug for TNBC management by the young investigator Dr. Juan Garona (National 
University of Quilmes, Bernal, Argentina) and the role of hypoxia in resistance to HER2-targeted antibody therapies by the PhD student Virginia Wolos from Dr. Gabriel Fiszman’s lab at Ángel H. Roffo Institute of Oncology, University of Buenos Aires, Argentina.

In Session 9, Dr. Steffi Oesterreich, from University of Pittsburgh, USA, showed current efforts to target mutant ER in breast cancer. She highlighted the different ER mutations that are present mainly in metastatic sites, but are absent in the primary tumor, and that may be studied in liquid biopsies. The mutations, including ESR1 hotspot point mutations at Y537S and D538G [39-44] and ESR1 fusion genes [25, $45,46]$ cause ligand independent activation of ER, resulting in endocrine resistant metastatic disease. In turn, Dr. Todd Miller (Dartmouth College, Lebanon, USA) focused on dormant ER + cells that start to grow after prolonged estrogen deprivation and show changes in metabolism towards fatty acid oxidation, opening the possibility of using this pathway to target dormant breast cancer cells [47].

Session 10 focused on the efforts to unveil mechanisms associated to novel targets that are important for the advancement of precision medicine. Dr. Violeta Serra from Vall d'Hebron Institut d'Oncologia (VHIO), Barcelona, Spain, reviewed the use of PARP inhibitors in BRCA1/2 mutated tumors and pointed out the relevance of using predictive biomarkers that correlate with PARPi response [48]. Dr. Santiago Bella (Sanatorio Allende and Clínica Universitaria Reina Fabiola, Córdoba, Argentina) focused on the current availability and use of CDK inhibitors for advanced breast cancer in South America. Dr. Dejan Juric (Massachusetts General Hospital, Boston, USA) conducted a journey on the use of PI3K inhibitors in clinical trials. He pointed out the importance of detecting PIK3CA mutations not only in solid tissue, but also in circulating DNA, and highlighted the relevance of combining endocrine therapies with CDK and PI3K inhibitors at early stages to avoid cross resistance [49]. Next, we had two short talks selected from posters. The $\mathrm{PhD}$ student Andrés Elia reported a new trial conducted by Dr. C. Lanari (IBYME-CONICET, Buenos Aires, Argentina) using the antiprogestin mifepristone in selected breast carcinomas with higher levels of isoform A than isoform B of PR. Finally, Dr. Fabiana Rossi, from Dr. M. Rossi Lab, at Austral University, Pilar, Argentina, showed promising pre-clinical data on the use of ubiquitin regulators as novel therapeutic targets [50].

On the last day of the meeting, in Session 12, Dr. Catherine Park (University of California, San Francisco, USA) talked about how local ablative treatment of metastasis could improve outcomes in patients with limited metastatic disease. Particularly, she made a special reference to clinical trials that test the efficacy of stereotactic ablative radiotherapy for the comprehensive treatment of oligometastatic cancers, as the SABR-COMET study [51]. In her talk, Dr. Victoria
Costanzo from Alexander Fleming Institute, Buenos Aires, Argentina, indicated therapeutic approaches presently being applied in Argentina for HER2 + patients. She emphasized that many new treatments have emerged in the last 2 years for the advanced disease. She highlighted that the challenge is how to adapt them to the treatment of the early disease to cure more patients. Then, Dr. Florencia Perazzo (CEMIC, Buenos Aires, Argentina) proposed that there is enough data to establish a proof of principle for immunotherapy for both early and advanced TNBC. However, she pointed out that new combination regimens and more refined biomarkers should be established to improve the response and to better identify the patients that most likely would benefit from immunotherapy [52]. Matthew Winder from CRUK Beatson Institute, UK, was selected to present his abstract in this session. He showed evidence of a critical pro-survival role for MCL-1, a BCL-2 family protein, in TNBC [53]. The results indicate that targeting this protein has an impact on tumor progression and cancer stem-cell like behavior in breast cancer.

In the last minisymposium, Dr. Pedram Razavi, from Memorial Sloan Kettering Cancer Center, New York, USA, indicated the relevance of serial liquid biopsies for detection of minimal residual disease, monitoring treatment and following clonal evolution of breast tumors [54, 55]. He also referred to the strengths and weak points of analyzing circulating tumor DNA [56]. Next, Dr. Osvaldo Podhajcer from Leloir institute, Buenos Aires, Argentina, referred to the Breast Cancer Study initiative performed by the USLatin America Cancer Research Network. More than 1000 tumors were characterized by gene-expression using cDNA microarrays and immunohistochemistry. Current studies, still unpublished, are presently carried on to analyze driven molecular pathways in the attempt to determine differences possibly associated to ancestry. Selected from the posters, the PhD student at IBYME-CONICET, Gabriela Pattacini referred to the establishment of patient derived xenograft (PDX) breast cancer bank in Buenos Aires, to test the efficacy of existing and novel drugs that would lead to faster development of new therapeutic approaches.

In the Closing conference, Dr. Charles Perou (UNC Lineberger Comprehensive Cancer Center, Chapel Hill, USA) started his lecture "Quantitative Medicine for Breast Cancer Patients" talking about the seminal paper that described for the first time the molecular portraits of breast cancer, highlighting the impact of that study on the understanding of breast cancer biology as well as the improvement of therapeutic decisions [57]. Then, he referred to the relevance of the "PAM50 ROR Score", which allows to accurately distinguish between luminal A and luminal B tumors. This analysis, together with tumor size, permits to quantitatively predict recurrence, and thus facilitate decision making on the appropriate length of endocrine therapy 
treatments [58]. Towards the end of his talk, Dr. Perou showed data underscoring the relevance of analyzing the immune anti-tumor activity as well as T-cell and B-cell signatures [59] to predict treatment response of triple negative and HER 2 + breast cancers [60]. This suggests that combined tumor and microenvironment molecular profiles may provide new predictor markers for prospective use in patients with different tumor subtypes.

Besides these extraordinary sessions our symposium also included three round tables integrated by South American investigators that discussed issues that concern the local community of breast cancer researchers and physicians. In the first one, focused on Genomics Platforms Dr. Ernesto Korbenfeld from Hospital Británico, Buenos Aires, presented the Oncotype DX platform, showing data indicating that some postmenopausal women with $\mathrm{ER}+$ / PR + /HER2- node positive breast cancer may safely avoid adjuvant chemotherapy, while premenopausal women on the same condition may still likely benefit from it. Next, Dr. Fernando Petracci (Alexander Fleming Institute, Buenos Aires) showed the clinical utility of MammaPrint and BluePrint for determining prognosis and guiding decisionmaking with respect to the administration of adjuvant chemotherapy in patients with newly diagnosed invasive breast cancer. The following round table on Biorepositories and Sample Management included five speakers: Dr. Andrea Bosaleh (Hospital Juan P. Garrahan, Buenos Aires, Argentina), Dr. Liliana Virginia Siede (UBA-UMSA, Buenos Aires, Argentina), Dr. Alfredo Molinolo (Moores Cancer Center, UCSD, San Diego, USA), Dr. Gonzalo Ardao (Army Central Hospital (HCFFAA), Montevideo, Uruguay) and Dr. Ana Palmero (Public Health Ministry, Argentina), all with expertise in tissue banking and pathology. The talks and discussions were focused on regulatory and general management issues as well as on technical aspects of tissue processing. The participants agreed that there are still several matters to work on in the interaction between biobank administrators and institutional review boards in order to make breast cancer samples more available to the local scientific community. Finally, the roles of government and non-government agencies, as well as industry, and their interaction in supporting and promoting breast cancer research were discussed in the third round table. Dr. Andrea Llera (Leloir Institute, Buenos Aires) mentioned aspects not commonly addressed when basic researchers apply to clinical grants such as costs associated to subject (patient) transportation, follow up, nursing and care, etc. Dr. Daniel Gomez (National University of Quilmes, Bernal, Argentina) referred to the possibility of participating from Argentina in international consortiums in the context of The European Union calls. Dr. Rosana Felice (GlaxoSmithKline, Argentina) talked about the experience of GSK in collaborating with Argentinian governmental agencies for funding translational projects. Finally, Judith Najdorf (University of Buenos Aires and CONICET, Argentina) provided her vision as a social scientist dedicated to the analysis of funding and evaluation of basic and translational scientific projects on health issues.

\section{Conclusions and Perspectives}

The first Buenos Aires Breast Cancer Symposium demonstrated that building a constructive network among breast cancer basic researchers and clinicians from all around the world with a relevant participation of South American researchers, who are commonly underrepresented in most international meetings, is possible. We, the organizers, received excellent feedbacks from all participants, including students who presented their results for the first time to an international audience, and experienced investigators working in the most important institutions around the world. Several new collaborative endeavors were initiated among participants even in the absence of face-to-face poster sessions, coffee breaks, corridors, meals and drinks, which usually are the most productive moments for establishing collaborations in a scientific meeting.

We hope that this meeting represents a new step forward in the advancement of breast cancer research in Argentina, setting a milestone from which the scientific and the medical communities may further contribute towards improvements in the diagnosis, treatment and management of breast cancer. Many challenges lie ahead, many related to the fact that we are a developing country. We trust that the community, the authorities, and industry may find a way to work together with scientists to achieve this common goal. This was our first trial, and we hope to repeat and improve this experience in the near future.

Acknowledgements The authors thank Mrs. Silvina Ceriani for her help with the organization of the meeting, Fundación IBYME for the administration of funds, and all chairs of Sessions, Round Tables and Posters that made an excellent job. We also thank Lobov, Microlat, GBO and APBiotech for their help in providing lab supplies to reimburse those that originally paid the registration fee. We specially thank the chairs Caroline Lamb, Isabel Luthy, Luisa Helguero, Martin Abba, Maria Roque and Laura Kass who helped us summarizing the talks of their respective sessions.

Authors Contributions All authors wrote the manuscript and approved the final manuscript.

Funding Funding for the meeting was received from Consejo Nacional de Investigaciones Cientificas y Tecnicas (CONICET) and Ministerio de Ciencia, Tecnología e Innovación Productiva (MINCYT) from Argentina and from the following pharmaceutical companies: Amgen, Pfizer, Novartis, Roche, and Gador Argentina. 


\section{Declarations}

Ethics Approval and Consent to Participate Not applicable.

Consent for Publication The manuscript has been read and approved by all authors. All participants have read and approved the content of the manuscript. All abstracts of the meeting including welcome and closing words will be published in a supplement of Medicina, Buenos Aires.

Conflict of Interest Dr. Edith C. Kordon is an Editorial board member of the Journal of Mammary Gland Biology and Neoplasia.

\section{References}

1. Greene GL, Closs LE, Fleming H, DeSombre ER, Jensen EV. Antibodies to estrogen receptor: immunochemical similarity of estrophilin from various mammalian species. Proc Natl Acad Sci USA. 1977;74(9):3681-5. https://doi.org/10.1073/pnas.74.9.3681.

2. Greene GL, Gilna P, Waterfield M, Baker A, Hort Y, Shine J. Sequence and expression of human estrogen receptor complementary DNA. Science. 1986;231(4742):1150-4. https://doi.org/10. 1126/science.3753802.

3. Shiau AK, Barstad D, Loria PM, Cheng L, Kushner PJ, Agard DA, Greene GL. The structural basis of estrogen receptor/coactivator recognition and the antagonism of this interaction by tamoxifen. Cell. 1998;95(7):927-37.

4. Fanning SW, Mayne CG, Dharmarajan V, Carlson KE, Martin TA, Novick SJ, Toy W, Green B, Panchamukhi S, Katzenellenbogen BS, Tajkhorshid E, Griffin PR, Shen Y, Chandarlapaty S, Katzenellenbogen JA, Greene GL. Estrogen receptor alpha somatic mutations Y537S and D538G confer breast cancer endocrine resistance by stabilizing the activating function- 2 binding conformation. eLife. 2016;5. https://doi.org/10.7554/eLife.12792.

5. Laine M, Fanning SW, Chang YF, Green B, Greene ME, Komm B, Kurleto JD, Phung L, Greene GL. Lasofoxifene as a potential treatment for therapy-resistant ER-positive metastatic breast cancer. Breast Cancer Res. 2021;23(1):54. https://doi.org/10.1186/ s13058-021-01431-w.

6. Zilli F, Marques Ramos P, Auf der Maur P, Jehanno C, Sethi A, Coissieux MM, Eichlisberger T, Sauteur L, Rouchon A, Bonapace L, Pinto Couto J, Rad R, Jensen MR, Banfi A, Stadler MB, Bentires-Alj M. The NFIB-ERO1A axis promotes breast cancer metastatic colonization of disseminated tumour cells. EMBO Mol Med. 2021;13(4): e13162. https://doi.org/10.15252/emmm. 202013162.

7. Obradovic MMS, Hamelin B, Manevski N, Couto JP, Sethi A, Coissieux MM, Munst S, Okamoto R, Kohler H, Schmidt A, Bentires-Alj M. Glucocorticoids promote breast cancer metastasis. Nature. 2019;567(7749):540-4. https://doi.org/10.1038/ s41586-019-1019-4.

8. Horlings HM, Weigelt B, Anderson EM, Lambros MB, Mackay A, Natrajan R, Ng CK, Geyer FC, van de Vijver MJ, Reis-Filho JS. Genomic profiling of histological special types of breast cancer. Breast Cancer ResTreat. 2013;142(2):257-69.

9. Pareja F, Weigelt B, Reis-Filho JS. Problematic breast tumors reassessed in light of novel molecular data. Mod Pathol. 2021;34(Suppl 1):38-47. https://doi.org/10.1038/ s41379-020-00693-7.

10. Lodillinsky C, Fuhrmann L, Irondelle M, Pylypenko O, Li XY, Bonsang-Kitzis H, Reyal F, Vacher S, Calmel C, De Wever O, Bieche I, Lacombe ML, Eijan AM, Houdusse A, Vincent-Salomon A, Weiss SJ, Chavrier P, Boissan M. Metastasis-suppressor NME1 controls the invasive switch of breast cancer by regulating MT1-MMP surface clearance. Oncogene. 2021;40(23):4019-32. https://doi. org/10.1038/s41388-021-01826-1.

11. Dwyer AR, Truong TH, Ostrander JH, Lange CA. 90 YEARS OF PROGESTERONE: Steroid receptors as MAPK signaling sensors in breast cancer: let the fates decide. J Mol Endocrinol. 2020;65(1):T35-48. https://doi.org/10.1530/JME-19-0274.

12. Truong TH, Dwyer AR, Diep CH, Hu H, Hagen KM, Lange CA. Phosphorylated Progesterone Receptor Isoforms Mediate Opposing Stem Cell and Proliferative Breast Cancer Cell Fates. Endocrinology. 2019;160(2):430-46. https://doi.org/10.1210/en. 2018-00990.

13. Williams MM, Spoelstra NS, Arnesen S, O’Neill KI, Christenson JL, Reese J, Torkko KC, Goodspeed A, Rosas E, Hanamura T, Sams SB, Li Z, Oesterreich S, Riggins RB, Jacobsen BM, Elias A, Gertz J, Richer JK. Steroid Hormone Receptor and Infiltrating Immune Cell Status Reveals Therapeutic Vulnerabilities of ESR1Mutant Breast Cancer. Cancer Res. 2021;81(3):732-46. https:// doi.org/10.1158/0008-5472.CAN-20-1200.

14. Sequeira GR, Sahores A, Dalotto-Moreno T, Perrotta RM, Pataccini G, Vanzulli SI, Polo ML, Radisky DC, Sartorius CA, Novaro V, Lamb CA, Rabinovich GA, Salatino M, Lanari C. Enhanced Antitumor Immunity via Endocrine Therapy Prevents Mammary Tumor Relapse and Increases Immune Checkpoint Blockade Sensitivity. Cancer Res. 2021;81(5):1375-87. https://doi.org/10.1158/00085472.CAN-20-1441.

15. Castellaro AM, Rodriguez-Baili MC, Di Tada CE, Gil GA. TumorAssociated Macrophages Induce Endocrine Therapy Resistance in ER+ Breast Cancer Cells. Cancers. 2019;11(2). https://doi.org/10. 3390/cancers 11020189.

16. Strietz J, Stepputtis SS, Follo M, Bronsert P, Stickeler E, Maurer J. Human Primary Breast Cancer Stem Cells Are Characterized by Epithelial-Mesenchymal Plasticity. Int J Mol Sci. 2021;22(4). https:// doi.org/10.3390/ijms22041808.

17. Ramesh V, Brabletz T, Ceppi P. Targeting EMT in Cancer with Repurposed Metabolic Inhibitors. Trends Cancer. 2020;6(11):94250. https://doi.org/10.1016/j.trecan.2020.06.005.

18. Eyre R, Alferez DG, Santiago-Gomez A, Spence K, McConnell JC, Hart C, Simoes BM, Lefley D, Tulotta C, Storer J, Gurney A, Clarke N, Brown M, Howell SJ, Sims AH, Farnie G, Ottewell PD, Clarke RB. Microenvironmental IL1beta promotes breast cancer metastatic colonisation in the bone via activation of Wnt signalling. Nature Commun. 2019;10(1):5016. https://doi.org/10.1038/ s41467-019-12807-0.

19. García Sola ME, Stedile M, Beckerman I, Kordon EC. An Integrative Single-cell Transcriptomic Atlas of the Post-natal Mouse Mammary Gland Allows Discovery of New Developmental Trajectories in the Luminal Compartment. J Mammary Gland Biol Neoplasia. 2021;26(1):29-42. https://doi.org/10.1007/ s10911-021-09488-1.

20. Majhi PD, Griner NB, Mayfield JA, Compton S, Kane JJ, Baptiste TA, Dunphy KA, Roberts AL, Schneider SS, Savage EM, Patel D, Blackburn AC, Maurus KJ, Wiesmuller L, Jerry DJ. Genetic modifiers regulating DNA replication and double-strand break repair are associated with differences in mammary tumors in mouse models of Li-Fraumeni syndrome. Oncogene. 2021;40(31):502637. https://doi.org/10.1038/s41388-021-01892-5.

21. Elsarraj HS, Hong Y, Limback D, Zhao R, Berger J, Bishop SC, Sabbagh A, Oppenheimer L, Harper HE, Tsimelzon A, Huang S, Hilsenbeck SG, Edwards DP, Fontes J, Fan F, Madan R, Fangman B, Ellis A, Tawfik O, Persons DL, Fields T, Godwin AK, Hagan CR, Swenson-Fields K, Coarfa C, Thompson J, Behbod F. BCL9/ STAT3 regulation of transcriptional enhancer networks promote DCIS progression. NPJ Breast Cancer. 2020;6:12. https://doi.org/ 10.1038/s41523-020-0157-z.

22. Xiao B, Zuo D, Hirukawa A, Cardiff RD, Lamb R, Sonenberg N, Muller WJ. Rheb1-Independent Activation of mTORC1 
in Mammary Tumors Occurs through Activating Mutations in mTOR. Cell Rep. 2020;31(4):107571. https://doi.org/10.1016/j. celrep.2020.107571.

23. Levine KM, Priedigkeit N, Basudan A, Tasdemir N, Sikora MJ, Sokol ES, Hartmaier RJ, Ding K, Ahmad NZ, Watters RJ, Weiss KR, Blohmer JU, Denkert C, Machleidt A, Karsten MM, Boisen MM, Elishaev E, Lucas PC, Lee AV, Oesterreich S. FGFR4 overexpression and hotspot mutations in metastatic ER+ breast cancer are enriched in the lobular subtype. NPJ Breast Cancer. 2019;5:19. https://doi.org/10.1038/s41523-019-0114-x.

24. Vareslija D, Priedigkeit N, Fagan A, Purcell S, Cosgrove N, O'Halloran PJ, Ward E, Cocchiglia S, Hartmaier R, Castro CA, Zhu L, Tseng GC, Lucas PC, Puhalla SL, Brufsky AM, Hamilton RL, Mathew A, Leone JP, Basudan A, Hudson L, Dwyer R, Das S, O'Connor DP, Buckley PG, Farrell M, Hill ADK, Oesterreich $S$, Lee AV, Young LS. Transcriptome Characterization of Matched Primary Breast and Brain Metastatic Tumors to Detect Novel Actionable Targets. J Natl Cancer Inst. 2019;111(4):388-98. https:// doi.org/10.1093/jnci/djy110.

25. Hartmaier RJ, Trabucco SE, Priedigkeit N, Chung JH, Parachoniak CA, Vanden Borre P, Morley S, Rosenzweig M, Gay LM, Goldberg ME, Suh J, Ali SM, Ross J, Leyland-Jones B, Young B, Williams C, Park B, Tsai M, Haley B, Peguero J, Callahan RD, Sachelarie I, Cho J, Atkinson JM, Bahreini A, Nagle AM, Puhalla SL, Watters RJ, Erdogan-Yildirim Z, Cao L, Oesterreich S, Mathew A, Lucas PC, Davidson NE, Brufsky AM, Frampton GM, Stephens PJ, Chmielecki $\mathrm{J}$, Lee AV. Recurrent hyperactive ESR1 fusion proteins in endocrine therapy-resistant breast cancer. Ann Oncol. 2018;29(4):872-80. https://doi.org/10.1093/annonc/mdy025.

26. Naser Al Deen N, Atallah Lanman N, Chittiboyina S, Lelièvre S, Nasr R, Nassar F, Zu Dohna H, AbouHaidar M, Talhouk R. A risk progression breast epithelial 3D culture model reveals $\mathrm{Cx} 43$ / hsa_circ_0077755/miR-182 as a biomarker axis for heightened risk of breast cancer initiation. Sci Rep. 2021;11(1):2626. https:// doi.org/10.1038/s41598-021-82057-y.

27. Duforestel M, Nadaradjane A, Bougras-Cartron G, Briand J, Olivier C, Frenel JS, Vallette FM, Lelièvre SA, Cartron PF. Glyphosate Primes Mammary Cells for Tumorigenesis by Reprogramming the Epigenome in a TET3-Dependent Manner. Front Genet. 2019;10:885. https://doi.org/10.3389/fgene.2019.00885.

28. Lelièvre SA, Bellanger M, Seewaldt V, Talhouk RS, Terry MB. Editorial: Perspectives in Primary Prevention Research for Breast Cancer: A Focus on Gene-Environment Interactions. Front Med (Lausanne). 2020;7:621959. https://doi.org/10.3389/fmed.2020. 621959.

29. Visser K, Zierau O, Macejova D, Goerl F, Muders M, Baretton GB, Vollmer G, Louw A. The phytoestrogenic Cyclopia extract, SM6Met, increases median tumor free survival and reduces tumor mass and volume in chemically induced rat mammary gland carcinogenesis. J Steroid Biochem Mol Biol. 2016;163:129-35. https://doi.org/10.1016/j.jsbmb.2016.04.019.

30. Helle J, Bader MI, Keiler AM, Zierau O, Vollmer G, Chittur SV, Tenniswood M, Kretzschmar G. Cross-Talk in the Female Rat Mammary Gland: Influence of Aryl Hydrocarbon Receptor on Estrogen Receptor Signaling. Environ Health Perspect. 2016;124(5):601-10. https://doi.org/10.1289/ehp.1509680.

31. Keiler AM, Macejova D, Dietz BM, Bolton JL, Pauli GF, Chen SN, van Breemen RB, Nikolic D, Goerl F, Muders MH, Zierau $\mathrm{O}$, Vollmer G. Evaluation of estrogenic potency of a standardized hops extract on mammary gland biology and on MNU-induced mammary tumor growth in rats. J Steroid Biochem Mol Biol. 2017;174:234-41. https://doi.org/10.1016/j.jsbmb.2017.09.020.

32. Beguelin W, Diaz Flaque MC, Proietti CJ, Cayrol F, Rivas MA, Tkach M, Rosemblit C, Tocci JM, Charreau EH, Schillaci R, Elizalde PV. Progesterone receptor induces ErbB-2 nuclear translocation to promote breast cancer growth via a novel transcriptional effect: ErbB-2 function as a coactivator of Stat3. Mol Cell Biol. 2010;30(23):5456-72.

33. Cordo Russo RI, Beguelin W, Diaz Flaque MC, Proietti CJ, Venturutti L, Galigniana N, Tkach M, Guzman P, Roa JC, O’Brien NA, Charreau EH, Schillaci R, Elizalde PV. Targeting ErbB-2 nuclear localization and function inhibits breast cancer growth and overcomes trastuzumab resistance. Oncogene. 2015;34(26):3413-28. https://doi.org/10.1038/ onc.2014.272.

34. Elizalde PV, Cordo Russo RI, Chervo MF, Schillaci R. ErbB-2 nuclear function in breast cancer growth, metastasis and resistance to therapy. Endocr Relat Cancer. 2016;23(12):T243-57. https:// doi.org/10.1530/ERC-16-0360.

35. Entenberg D, Voiculescu S, Guo P, Borriello L, Wang Y, Karagiannis GS, Jones J, Baccay F, Oktay M, Condeelis J. A permanent window for the murine lung enables high-resolution imaging of cancer metastasis. Nat Methods. 2018;15(1):73-80. https://doi.org/ 10.1038/nmeth.4511.

36. Pignatelli J, Bravo-Cordero JJ, Roh-Johnson M, Gandhi SJ, Wang Y, Chen X, Eddy RJ, Xue A, Singer RH, Hodgson L, Oktay MH, Condeelis JS. Macrophage-dependent tumor cell transendothelial migration is mediated by Notch1/Mena(INV)-initiated invadopodium formation. Sci Rep. 2016;6:37874. https://doi.org/10.1038/ srep37874.

37. Linde N, Casanova-Acebes M, Sosa MS, Mortha A, Rahman A, Farias E, Harper K, Tardio E, Reyes Torres I, Jones J, Condeelis J, Merad M, Aguirre-Ghiso JA. Macrophages orchestrate breast cancer early dissemination and metastasis. Nature Com. 2018;9(1):21. https://doi.org/10.1038/s41467-017-02481-5.

38. Kai F, Drain AP, Weaver VM. The Extracellular Matrix Modulates the Metastatic Journey. Dev Cell. 2019;49(3):332-46. https://doi. org/10.1016/j.devcel.2019.03.026.

39. Bahreini A, Li Z, Wang P, Levine KM, Tasdemir N, Cao L, Weir HM, Puhalla SL, Davidson NE, Stern AM, Chu D, Park BH, Lee $\mathrm{AV}$, Oesterreich S. Mutation site and context dependent effects of ESR1 mutation in genome-edited breast cancer cell models. Breast Cancer Res. 2017;19(1):60. https://doi.org/10.1186/ s13058-017-0851-4.

40. Wang P, Bahreini A, Gyanchandani R, Lucas PC, Hartmaier RJ, Watters RJ, Jonnalagadda AR, Trejo Bittar HE, Berg A, Hamilton RL, Kurland BF, Weiss KR, Mathew A, Leone JP, Davidson NE, Nikiforova MN, Brufsky AM, Ambros TF, Stern AM, Puhalla SL, Lee AV, Oesterreich S. Sensitive Detection of Mono- and Polyclonal ESR1 Mutations in Primary Tumors, Metastatic Lesions, and Cell-Free DNA of Breast Cancer Patients. Clin Cancer Res. 2016;22(5):1130-7. https://doi.org/10.1158/1078-0432. CCR-15-1534.

41. Hermida-Prado F, Jeselsohn R. The ESR1 Mutations: From Bedside to Bench to Bedside. Cancer Res. 2021;81(3):537-8. https:// doi.org/10.1158/0008-5472.CAN-20-4037.

42. Jeselsohn R, Yelensky R, Buchwalter G, Frampton G, MericBernstam F, Gonzalez-Angulo AM, Ferrer-Lozano J, PerezFidalgo JA, Cristofanilli M, Gomez H, Arteaga CL, Giltnane J, Balko JM, Cronin MT, Jarosz M, Sun J, Hawryluk M, Lipson D, Otto G, Ross JS, Dvir A, Soussan-Gutman L, Wolf I, Rubinek T, Gilmore L, Schnitt S, Come SE, Pusztai L, Stephens P, Brown M, Miller VA. Emergence of constitutively active estrogen receptoralpha mutations in pretreated advanced estrogen receptor-positive breast cancer. Clin Cancer Res. 2014;20(7):1757-67.

43. Toy W, Shen Y, Won H, Green B, Sakr RA, Will M, Li Z, Gala K, Fanning S, King TA, Hudis C, Chen D, Taran T, Hortobagyi G, Greene G, Berger M, Baselga J, Chandarlapaty S. ESR1 ligandbinding domain mutations in hormone-resistant breast cancer. Nat Genet. 2013;45(12):1439-45.

44. Schiavon G, Hrebien S, Garcia-Murillas I, Cutts RJ, Pearson A, Tarazona N, Fenwick K, Kozarewa I, Lopez-Knowles E, Ribas R, Nerurkar A, Osin P, Chandarlapaty S, Martin LA, Dowsett M, 
Smith IE, Turner NC. Analysis of ESR1 mutation in circulating tumor DNA demonstrates evolution during therapy for metastatic breast cancer. Sci Transl Med. 2015;7(313):313ra182. https://doi. org/10.1126/scitranslmed.aac7551.

45. Lei JT, Shao J, Zhang J, Iglesia M, Chan DW, Cao J, Anurag M, Singh P, He X, Kosaka Y, Matsunuma R, Crowder R, Hoog J, Phommaly C, Goncalves R, Ramalho S, Peres RMR, Punturi N, Schmidt C, Bartram A, Jou E, Devarakonda V, Holloway KR, Lai WV, Hampton O, Rogers A, Tobias E, Parikh PA, Davies SR, Li S, Ma CX, Suman VJ, Hunt KK, Watson MA, Hoadley KA, Thompson EA, Chen X, Kavuri SM, Creighton CJ, Maher CA, Perou CM, Haricharan S, Ellis MJ. Functional Annotation of ESR1 Gene Fusions in Estrogen Receptor-Positive Breast Cancer. Cell Rep. 2018;24(6):1434-44 e1437. https://doi.org/10.1016/j. celrep.2018.07.009.

46. Lei JT, Gou X, Ellis MJ. ESR1 fusions drive endocrine therapy resistance and metastasis in breast cancer. Mol Cell Oncol. 2018;5(6):e1526005. https://doi.org/10.1080/23723556.2018. 1526005 .

47. Hampsch RA, Wells JD, Traphagen NA, McCleery CF, Fields JL, Shee K, Dillon LM, Pooler DB, Lewis LD, Demidenko E, Huang YH, Marotti JD, Goen AE, Kinlaw WB, Miller TW. AMPK Activation by Metformin Promotes Survival of Dormant ER(+) Breast Cancer Cells. Clin Cancer Res. 2020;26(14):3707-19. https://doi. org/10.1158/1078-0432.CCR-20-0269.

48. Castroviejo-Bermejo M, Cruz C, Llop-Guevara A, GutierrezEnriquez S, Ducy M, Ibrahim YH, Gris-Oliver A, Pellegrino B, Bruna A, Guzman M, Rodriguez O, Grueso J, Bonache S, MolesFernandez A, Villacampa G, Viaplana C, Gomez P, Vidal M, Peg V, Serres-Creixams X, Dellaire G, Simard J, Nuciforo P, Rubio IT, Dienstmann R, Barrett JC, Caldas C, Baselga J, Saura C, Cortes J, Deas O, Jonkers J, Masson JY, Cairo S, Judde JG, O'Connor MJ, Diez O, Balmana J, Serra V. A RAD51 assay feasible in routine tumor samples calls PARP inhibitor response beyond BRCA mutation. EMBO Mol Med. 2018;10(12). https://doi.org/10. 15252/emmm.201809172.

49. Juric D, Janku F, Rodon J, Burris HA, Mayer IA, Schuler M, Seggewiss-Bernhardt R, Gil-Martin M, Middleton MR, Baselga J, Bootle D, Demanse D, Blumenstein L, Schumacher K, Huang A, Quadt C, Rugo HS. Alpelisib Plus Fulvestrant in PIK3CAAltered and PIK3CA-Wild-Type Estrogen Receptor-Positive Advanced Breast Cancer: A Phase 1b Clinical Trial. JAMA Oncol. 2019;5(2):e184475. https://doi.org/10.1001/jamaoncol.2018.4475.

50. Rossi FA, Enrique Steinberg JH, Calvo Roitberg EH, Joshi MU, Pandey A, Abba MC, Dufrusine B, Buglioni S, De Laurenzi V, Sala G, Lattanzio R, Espinosa JM, Rossi M. USP19 modulates cancer cell migration and invasion and acts as a novel prognostic marker in patients with early breast cancer. Oncogenesis. 2021;10(3):28. https://doi.org/10.1038/s41389-021-00318-x.

51. Palma DA, Olson R, Harrow S, Gaede S, Louie AV, Haasbeek C, Mulroy L, Lock M, Rodrigues GB, Yaremko BP, Schellenberg D, Ahmad B, Senthi S, Swaminath A, Kopek N, Liu M, Moore K, Currie S, Schlijper R, Bauman GS, Laba J, Qu XM, Warner A, Senan S. Stereotactic Ablative Radiotherapy for the Comprehensive Treatment of Oligometastatic Cancers: Long-Term Results of the SABR-COMET Phase II Randomized Trial. J Clin Oncol. 2020;38(25):2830-8. https://doi.org/10.1200/JCO.20.00818.

52. Isaacs J, Anders C, McArthur H, Force J. Biomarkers of Immune Checkpoint Blockade Response in Triple-Negative Breast Cancer. Curr Treat Options Oncol. 2021;22(5):38. https://doi.org/10.1007/ s11864-021-00833-4.
53. Campbell KJ, Mason SM, Winder ML, Willemsen RBE, Cloix C, Lawson H, Rooney N, Dhayade S, Sims AH, Blyth K, Tait SWG. Breast cancer dependence on MCL-1 is due to its canonical anti-apoptotic function. Cell Death Differ. 2021. https://doi.org/ 10.1038/s41418-021-00773-4.

54. Razavi P, Li BT, Brown DN, Jung B, Hubbell E, Shen R, Abida W, Juluru K, De Bruijn I, Hou C, Venn O, Lim R, Anand A, Maddala T, Gnerre S, Vijaya Satya R, Liu Q, Shen L, Eattock N, Yue J, Blocker AW, Lee M, Sehnert A, Xu H, Hall MP, Santiago-Zayas A, Novotny WF, Isbell JM, Rusch VW, Plitas G, Heerdt AS, Ladanyi M, Hyman DM, Jones DR, Morrow M, Riely GJ, Scher HI, Rudin CM, Robson ME, Diaz LA Jr, Solit DB, Aravanis AM, Reis-Filho JS. High-intensity sequencing reveals the sources of plasma circulating cell-free DNA variants. Nat Med. 2019;25(12):1928-37. https://doi.org/10.1038/s41591-019-0652-7.

55. Razavi P, Dickler MN, Shah PD, Toy W, Brown DN, Won HH, Li BT, Shen R, Vasan N, Modi S, Jhaveri K, Caravella BA, Patil S, Selenica P, Zamora S, Cowan AM, Comen E, Singh A, Covey A, Berger MF, Hudis CA, Norton L, Nagy RJ, Odegaard JI, Lanman RB, Solit DB, Robson ME, Lacouture ME, Brogi E, Reis-Filho JS, Moynahan ME, Scaltriti M, Chandarlapaty S. Alterations in PTEN and ESR1 promote clinical resistance to alpelisib plus aromatase inhibitors. Nature Cancer. 2020;1(4):382-93. https://doi.org/10. 1038/s43018-020-0047-1.

56. Tsui DWY, Cheng ML, Shady M, Yang JL, Stephens D, Won H, Srinivasan P, Huberman K, Meng F, Jing X, Patel J, Hasan M, Johnson I, Gedvilaite E, Houck-Loomis B, Socci ND, Selcuklu SD, Seshan VE, Zhang H, Chakravarty D, Zehir A, Benayed R, Arcila M, Ladanyi M, Funt SA, Feldman DR, Li BT, Razavi P, Rosenberg J, Bajorin D, Iyer G, Abida W, Scher HI, Rathkopf D, Viale A, Berger MF, Solit DB. Tumor fraction-guided cell-free DNA profiling in metastatic solid tumor patients. Genome Med. 2021;13(1):96. https://doi.org/10.1186/s13073-021-00898-8.

57. Perou CM, Sorlie T, Eisen MB, van de RM, Jeffrey SS, Rees CA, Pollack JR, Ross DT, Johnsen H, Akslen LA, Fluge O, Pergamenschikov A, Williams C, Zhu SX, Lonning PE, Borresen-Dale AL, Brown PO, Botstein D, . Molecular portraits of human breast tumours. Nature. 2000;406(6797):747-52.

58. Parker JS, Mullins M, Cheang MC, Leung S, Voduc D, Vickery T, Davies S, Fauron C, He X, Hu Z, Quackenbush JF, Stijleman IJ, Palazzo J, Marron JS, Nobel AB, Mardis E, Nielsen TO, Ellis MJ, Perou CM, Bernard PS. Supervised risk predictor of breast cancer based on intrinsic subtypes. J Clin Oncol. 2009;27(8):1160-7.

59. Hollern DP, Xu N, Thennavan A, Glodowski C, Garcia-Recio S, Mott KR, He X, Garay JP, Carey-Ewend K, Marron D, Ford J, Liu S, Vick SC, Martin M, Parker JS, Vincent BG, Serody JS, Perou CM. B cells and T follicular helper cells mediate response to checkpoint inhibitors in high mutation burden mouse models of breast cancer. Cell. 2019;179(5):1191-206 e1121. https://doi. org/10.1016/j.cell.2019.10.028.

60. Fernandez-Martinez A, Krop IE, Hillman DW, Polley MY, Parker JS, Huebner L, Hoadley KA, Shepherd J, Tolaney S, Henry NL, Dang C, Harris L, Berry D, Hahn O, Hudis C, Winer E, Partridge A, Perou CM, Carey LA. Survival, Pathologic Response, and Genomics in CALGB 40601 (Alliance), a Neoadjuvant Phase III Trial of Paclitaxel-Trastuzumab With or Without Lapatinib in HER2-Positive Breast Cancer. J Clin Oncol. 2020;38(35):4184-93. https://doi.org/10.1200/JCO.20.01276.

Publisher's Note Springer Nature remains neutral with regard to jurisdictional claims in published maps and institutional affiliations. 